\title{
Global Warming: The Juggernaut Interpretation
}

\author{
Jan-Erik Lane ${ }^{1 *}$ \\ ${ }^{1}$ Public Policy Institute, Belgrade \\ *Jan-Erik Lane, E-mail: janeklane@gmail.com \\ Address: 10 Charles Humbert, 1205 Geneva; 559 A, 3rd Floor, Thuya Street, 9th Quarter, Yangon, \\ Myanmar. \\ Received: October 24, 2016 Accepted: October 31, 2016 Online Published: November 3, 2016 \\ doi:10.22158/se.v1n2p157 URL: http://dx.doi.org/10.22158/se.v1n2p157
}

\begin{abstract}
Sincere and profound pessimism about the prospects of implementation success for the COP21 project is warranted. The setting up of the Super Fund is a necessity for avoiding collective choice and decision paradoxes like PD games, sub-optimization and second best solutions. Without massive financial assistance, there will occur widespread reneging on the COP21 objectives (Goal I-III). The system of United Nations Climate Change Conferences, i.e., the yearly conferences held in the framework of the United Nations Framework Convention on Climate Change (UNFCCC), does not offer an organization that is up to the coordination tasks involved in halting climate change. Massive new management is required in each country to fulfill the COP21 objectives.
\end{abstract}

\section{Keywords}

Climate change, global warming, management tasks, social sciences' choice and decision paradoxes, longitudinal Kaya model, emissions-energy-GDP links, comparative country predicaments, Super Fund

\section{Introduction: Wildavsky's Hiatus}

Perhaps optimism about halting climate change is growing now, despite all negative environmental reports about for instance dying oceans. Climate change and what it entails is given much more attention after the COP21 Agreement in Paris. There are almost weekly conferences about global warming and the debate is intense all over the globe. The social science aspects of global warming policy-making, however, have not been pointed out. This is a problematic by itself that severely reduces the likelihood of successful implementation of the goals of the COP21 Agreement (Goal I, Goal II and Goal III in global decarbonistion). The basic Wildavsky $(1979,1987)$ gulf between policy promises and real life implementation outcomes is bound to plague the efforts at coordination to halt the climate change process in the decades to come. 


\section{Natural Sciences on Climate Change}

It is quite understandable that the focus in all the international conferences, some of which are now speaking of COP22 meetings, is upon the natural science issues in climate change. They deal with how dangerous the global warming process could be as well as the feasibility of halting this trend in the 21rdt century by various measures, like for instance carbon capture. Yet, by neglecting some very relevant social science models, the COP21 approach of decarburization will run into major difficulties, already in the next decade. Can really international governance together with states coordination deliver policies and will they be implemented in a decentralized approach? Tis question is most relevant, even when the natural sciences and technology arrives at conclusive answers to the major issues in climate change.

It seems to me that the key issues in the global climate change debate concerns inter alia the following:

1) What more precisely is the link between the amount of carbon in the atmosphere and the rise of temperature, in sea and $\mathrm{n}$ land? Is it a linear or non-linear link? Thresholds? Reversibility?

2) How and when will rising temperatures in sea and at land affect basic environmental aspects, like the ice layers and the frozen waters as well as glaciers?

3) How much carbon will be stocked in the atmosphere in this century, given alternative scenarios of emissions and natural carbon uptake? How dangerous could increase GHG:s like methane be?

4) Is it at all feasible to accomplish massive decarbonisation of the air by means of carbon sequestration at what costs?

Having full knowledge about all these issues would improve much upon the theories of global warming and would be extremely useful in practice when policies are to me made about decarbonisation.

Yet, they do not comprise the implications of lessons of the social sciences for global governance, coordination and policy making. The crux of the matter is what I call the Wildavsky hiatus: policies however appealing are bound to fail when put in practice, as no policy is self-implementable (Pressman \& Wildavsky, 1973, 1984). To grasp the feasibility of the COP21 project and its three goals of decarbonisation, one must understand the implementation deficit and the coordination failures. I will spell out these concepts here in relation to the COP21 framework, and its three objectives, namely:

a) Halting the increase in carbon emission up to 2020 (Goal I);

b) Reducing CO2:s up until 2030 with 40 per cent (Goal II);

c) Achieve more less total decarbonisation until 2075 (Goal III).

It is up to the governments of the countries to implement these goals with rather weak overview from international governance but with the promise of assistance from a huge Super Fund. What, then, are the INCENTIVES involved in decentralized decarbonisation a la COP21? To discuss decarbonisation feasibility along the three goals - Goal I, Goal II and Goal III-one need to take into account the restrictions on human action and interaction in social systems, spelled out in economic decision theory and game theory. 


\section{Fundamental Economic Restriction: Kaya's Model}

The basic theoretical effort to model the greenhouse gases, especially $\mathrm{CO} 2 \mathrm{~s}$, in terms of a so-called identity is the deterministic Kaya equation. The Kaya identity, "I = PAT"-model type, describes environmental (I)mpactagainst the (P)opulation, (A)ffluence and (T)echnology. Technology covers energy use per unit of GDP as well as carbon emissions per unit of energy consumed (Kaya \& Yokoburi, 1997).

\subsection{Theory}

In theories of climate change, the focus is upon so-called anthropogenic causes of global warming through the release of Greenhouse Gases (GHG). To halt the growth of the GHG:s, of which CO2:s make up about 70 per cent, one must theorize the increase in $\mathrm{CO} 2$ :s over time (longitudinally) and its variation among countries (cross-sectionally). As a matter of fact, $\mathrm{CO} 2$ :s have very strong mundane conditions in human needs and social system prerequisites. Besides the breading of living species, like Homo sapiens for instance, energy consumption plays a major role. As energy is the capacity to do work, it is absolutely vital for the economy in a wide sense, covering both the official and the unofficial sides of the economic system of a country. The best model of carbon emissions to this day is the so-called Kaya model. It reads as follows in its standard equation version-Kaya's identity:

“(E1) Kaya's identity projects future carbon emissions on changes in Population (in billions), economic activity as GDP per capita (in thousands of \$US(1990)/person year), energy intensity in Watt years/dollar, and carbon intensity of energy as Gton $\mathrm{C}$ as $\mathrm{CO}_{2}$ per TeraWatt year". (http://climatemodels.uchicago.edu/kaya/kaya.doc.html)

Concerning the equation (E1), it may seem premature to speak of a law or identity that explains carbon emissions completely, as if the Kaya identity is a deterministic natural law. It will not explain all the variation, as there is bound to be other factors that impact, at least to some extent. Thus, it is more proper to formulate it as a stochastic law-like proposition, where coefficients will be estimate using various data sets, without any assumption about stable universal parameters. Thus, we have this equation format for the Kaya probabilistic law-like proposition, as follows:

(E2) Multiple Regression: $Y=a+b_{1} X_{1}+b_{2} X_{2}+b_{3} X_{3}+\ldots+b_{t} X_{t}+u$

Note: $\mathrm{Y}=$ the variable that you are trying to predict (dependent variable); $\mathrm{X}=$ the variable that you are using to predict $\mathrm{Y}$ (independent variable); $\mathrm{a}=$ the intercept; $\mathrm{b}=$ the slope; $\mathrm{u}=$ the regression residual. Note: http://www.investopedia.com/terms/r/regression.asp\#ixzz4Mg4Eyugw

Thus, using the Kaya model for empirical research on global warming, the following anthropegenic conditions would affect positively carbon emissions:

(E3) $\mathrm{CO} 2 \mathrm{~s}=\mathrm{F}(\mathrm{GDP} /$ capita, Population, Energy intensity, Carbon intensity), in a stochastic form with a residual variance, all to be estimated on data from some 59 countries.

\subsection{Empirical Result}

I make an empirical estimation of this probabilistic Kaya model-the longitudinal test for World data 1990-2015: (E4) $\mathrm{Ln} \mathrm{CO} 2=0,62 * \mathrm{LN}$ Population + 1,28* LN(GDP/Capita) $+0,96 * \mathrm{LN}($ Energy/GDP); 
$\mathrm{R} 2=0.998$.

Note: $\mathrm{LN} \mathrm{CO} 2=\mathrm{k} 1 * \mathrm{LN}(\mathrm{GDP} /$ Capita $)+\mathrm{k} 2 *$ (dummy for Energy Intensity) $+\mathrm{k} 3 *$ (LN Population); $(\mathrm{N}=59)$

Estimating a longitudinal Kaya model entails that total GHG:s go with larger total GDP. To make the dilemma of energy versus emissions even worse, we show in Figure 1 that GDP increase with the augmentation of energy per capita. Decarbonisation is the promise to undo these dismal links by making GDP and energy consumption rely upon carbon neutral energy resources, like modern renewables and atomic energy.

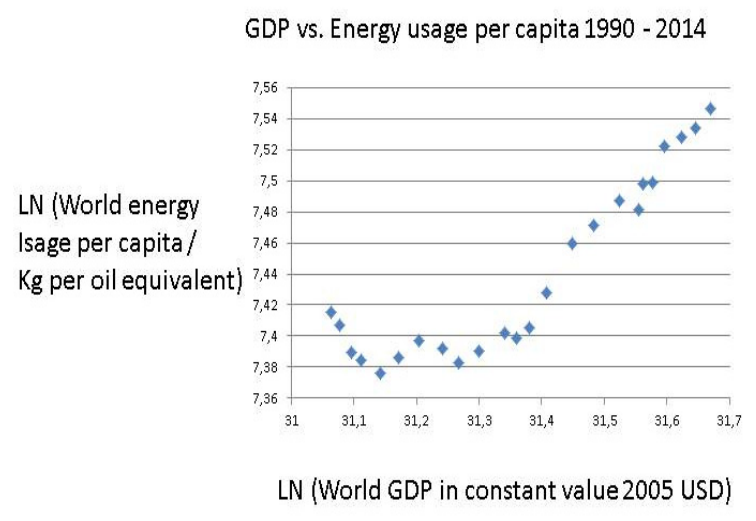

Figure 1. GDP against Energy per Person (All Countries)

\subsection{Research Approach}

We model this energy-emission dilemma for the countries of the COP21 project. To understand the predicament of Third World countries, we need to know whether GHC:s or CO2:s are still increasing (Goal I) and what the basic structure of the energy mix is (Goal II). Thus, I suggest: < GDP - GHG (CO2) link, energy mix $>$, as a model of the decarbonisation feasibility in some Third World countries, to be analysed below, following the so-called "Kaya" model. The first concept taps the feasibility of Goal I: halting the growth of GHG:s or CO2:s, whereas the other concepts targets the role of fossil fuels and wood coal like charcoal.

The difference between global warming concern and general environmentalism appears clearly in the evaluation of atomic power. For reducing climate change, nuclear power is vital, but for environmentalism atomic power remains a threat. From a short-term perspective, the global warming concerns should trump the fear of radioactive dissemination, as global warming will hit mankind much sooner. In the Third World, nuclear power plants are increasing in number, whereas in the mature economies their number is being reduced. New nuclear technology is much safer, why also advanced countries should use this option, like for instance the UK. 


\section{Comparative Country Enquiry}

Just because there is an agreement it does not entail it will be respected. Even if respecting the promises made is the best strategy for all partners to the dal, each individual has an incentive to renege upon the agreement. In two-person game theory, a few much discussed models portray coordination failures, and they are applicable to governments as well as international governance. If, as shown above with the Kaya model, decarbonisatin may be costly, hurting economic development, then perhaps a country may simply go its own way, leaving it up to the other(s) to handle the externalities in global warming. Why make costly contributions to collective action? Remember that small countries do not matter much (N-1 problematic) and huge countries would have to share the benefits with all others (I/N problematic).

The interaction between nations and their governments can be of two kinds: zero sum game or variable sum game. Halting the climate change process constitutes a Pareto optimal goal for all participants with means of collective action, coordination either by themselves or with a third party, an international governance body like that of the UNFCCC. However, coordination may fail to reach a set of Pareto optimal outcomes, as the choice participants chose Pareto inferior strategies due to self-interest seeking with guile. Coordination failures arise when individual rationality prevails over collective rationality:

-Reneging (PD game);

-Threat (Chicken game);

-Sub-optimality (Negotiation game);

-Second best solutions (Assurance game).

We will give some examples of these possible coordination failures in the management of the global warming process, where also financial help from a Super Fund enters the gaming strategies. Thus for instance, poor countries with huge total emissions may demand much larger reductions percentage wise from rich countries with high per capita emissions. Unless accepted, they renege upon the COP21 objectives of decarbonisation.

\subsection{GDP-GHG (CO2) Links and Energy Consumption Mix}

I will analyse a few important countries in a comparative fashion so that they can be compared systematically. Two diagrams will be presented for each country, related to the research approach above. First, the COP21 Goal I will be tapped by looking at the curve between GDP and CO2:s (GHG:s), whether is rising or declining and whether it slopes outward or inward. Second, the COP21 Goal II is enquired into, as the energy consumption mix is portrayed: the more reliance upon fossil fuels and charcoal, the more costly the energy transition. What matters in both diagrams are both absolute and relative numbers. Thus, the coal share of energy resources may go down, but if total energy consumed is up, emissions will remain at a high level.

\subsection{Real Reneging Option (PD Games)}

A set of countries with huge population at a low level income per person will find the COP21 objectives too exigent. They have to plan for more of energy in order to strengthen economic 
development against widespread poverty amidst string population growth. These huge poor countries with large emissions can only promote Goal I and Goal II, if supported by the Super Fund.

India will certainly appeal to the same problematic, namely per capita or aggregate emissions. The country is more negative than China to cut GHG emissions, as it is in an earlier stage of industrialization and urbanization. Figure 2 shows the close connection between $\mathrm{CO} 2$ emissions and GDP for this giantnation.

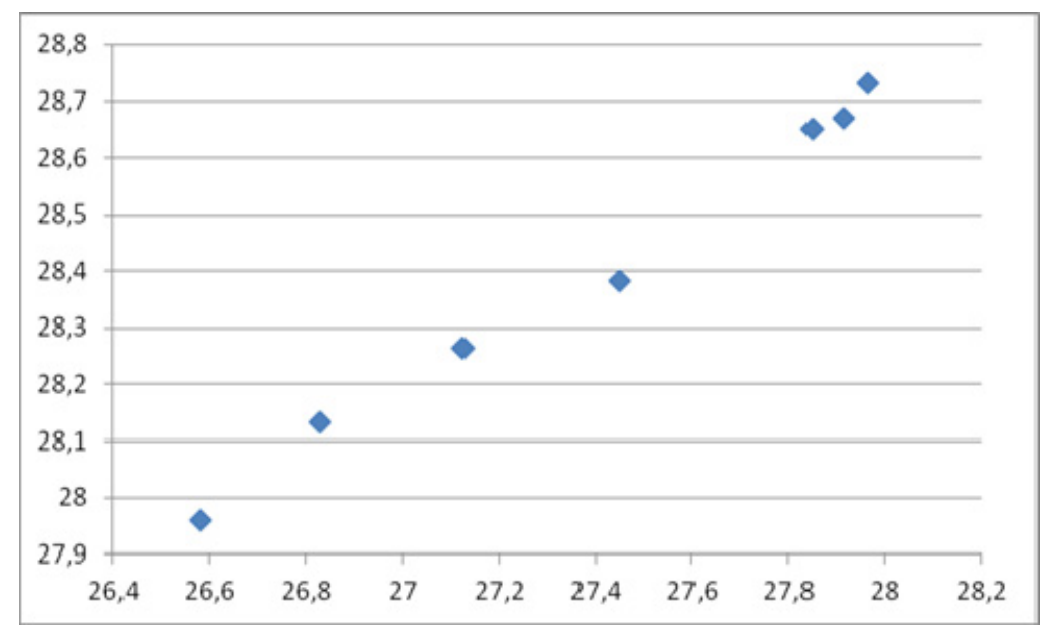

Figure 2. India: $y=0,7702 x+6,79 ; R^{2}=0,99$

Note. $\mathrm{GHG}=\mathrm{y}$-axis, GDP $=\mathrm{x}$-axis.

India needs cheap energy for its industries, transportation and heating (Figure 3) as well as electrification. From where will it come? India has water power and nuclear energy, but relies most upon coal, oil and gas as power source. It has strong ambitions for the future expansion of energy, but how is it to be generated, the world asks. India actually has one of the smallest numbers for energy per capita, although it produces much energy totally. Figure 3 shows its energy mix where renewables play a bigger role than in for instance China. 


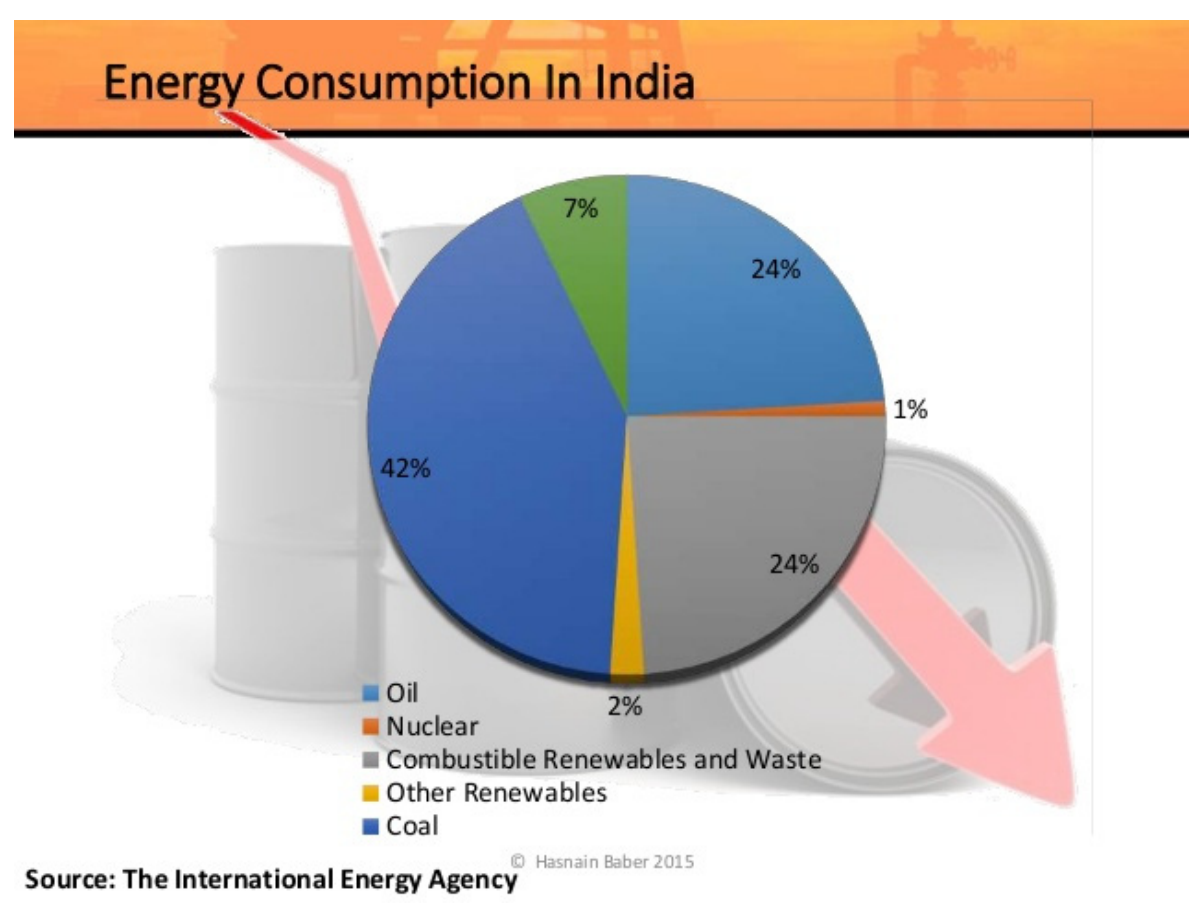

Figure 3. Energy in India

India needs especially electricity, as 300 million inhabitants lack access to it. The country is heavily dependent upon fossil fuels (70 per cent), although to a less extent than China. Electricity can be generated by hydro power and nuclear power, both of which India employs. Yet, global warming reduces the capacity of hydro power and nuclear power meets with political resistance. Interestingly, India uses much biomass and waste for electricity production, which does not always reduce GHG emissions. India's energy policy will be closely watched by other governments and NGO:s after 2018. Indonesia

One may guess correctly that countries that try hard to "catch-up" will have increasing emissions. This was true of China and India. Let us look at three more examples, like, e.g., giant Indonesia—now the fourth largest emitter of GHG:s and CO2:s in the world (Figure 4). 


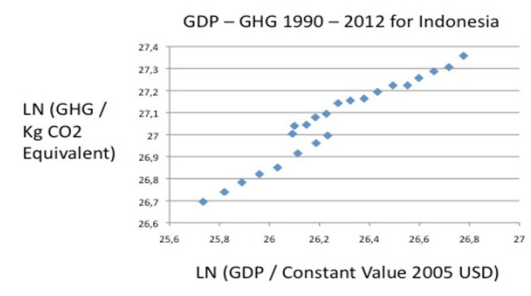

Figuer 4. Indonesia: $y=0,9452 x+1,58 ; R^{2}=0,89$

Indonesia

Indonesia is a coming giant, both economically and sadly in terms of pollution. Figure 9 reminds of the upward trend for China and India. However, matters are even worse for Indonesia, as the burning of the rain forest on Kalimantan and Sumatra augments the GHG emissions very much. Figure 5 presents the energy mix for this huge country in terms of population and territory.

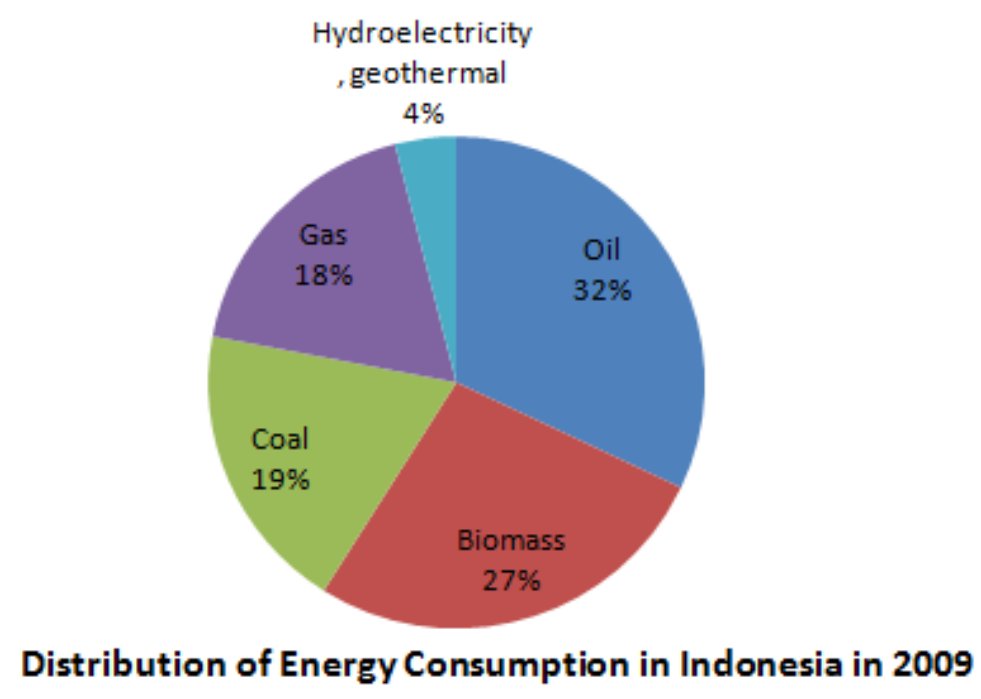

Figure 5. Indonesian Energy

http://missrifka.com/energy-issue/recent-energy-status-in-indonesia.html

Only 4 per cent comes from hydro power with 70 per cent from fossil fuels and the remaining 27 per cent from biomass, which alas also pollutes.

\section{Pakistan}

The same upward trend for emissions holds for another major developing country with huge population, namely Pakistan (Figure 6). 


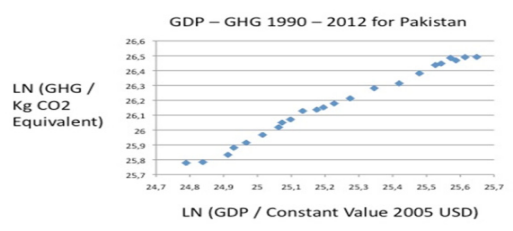

Figure 6. Pakistan: Ln (GHG/Kg CO2 eq and LN (GDP/Constant Value 2005 USD))

The amount of GHG emissions is rather large for Pakistan, viewed on aggregate. Pakistan is mainly reliant upon fossil fuels (Figure 7).

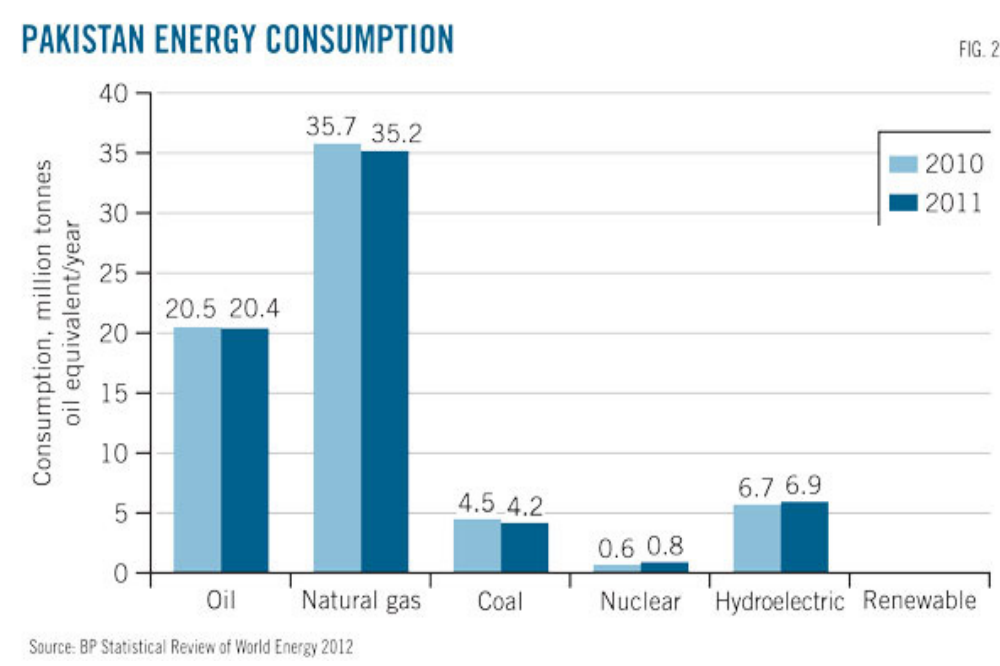

Figure 7. Energy Consumption

But Pakistan employs a considerable portion of hydropower -13 per cent - and a minor portion of nuclear power, which is a positive.

Bangladesh

Moving on to another giant nation in South Asia, Bangladesh, we find an entirely different set of conditions for implementing COP21. Figure 10 shows that the major GHC of $\mathrm{CO} 2$ :s follows economic development closely. 


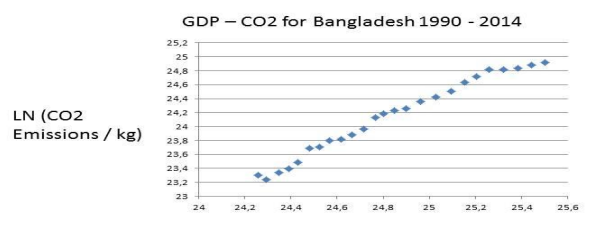

LN (GDP / Constant Value 2005 USD)

Figure 8. Bangladesh's GDP-CO@Link $\left(y=1,43 x, R^{2}=0,98\right)$

Yet energy consumption is based on a different energy mix, compared with for instance India. Figure 9 pins down the large role of traditional renewables like wood, charcoal and dung as well as the heavy contribution of oil and gas. Bangladesh needs external support for developing modern renewables, like solar, wind and geo-thermal power sources.

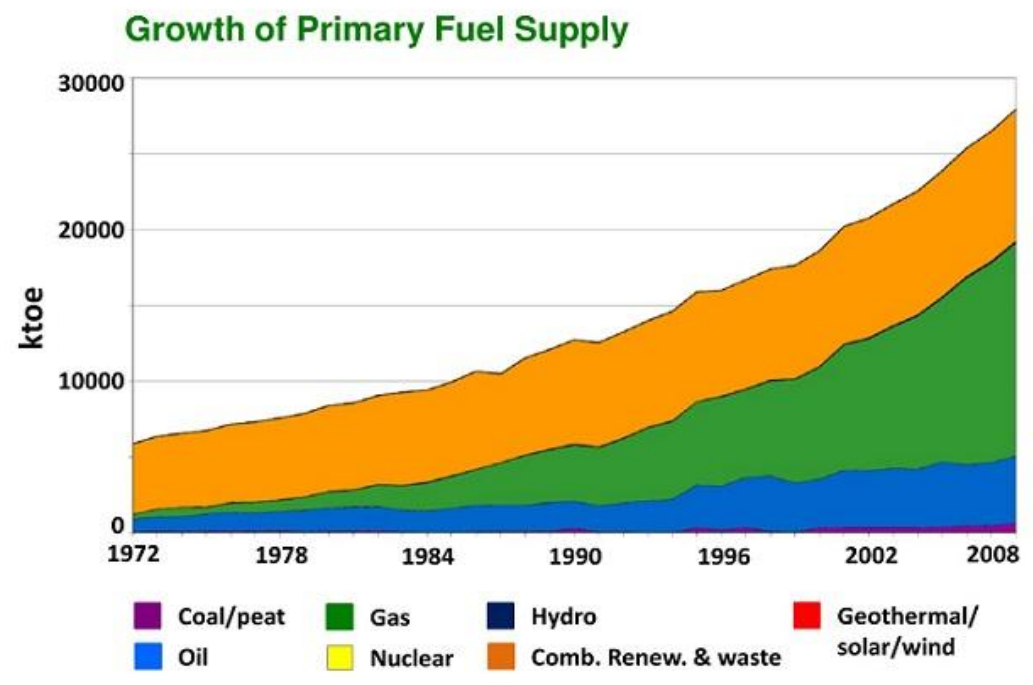

Figure 9. Energy Mix

Source: Energy Scenario in Bangladesh from 1972-2008 (Orange: Biomass, Green: Gas, Blue: Oil).

Sri Lanka

When examining small but populous Sri Lanka, one sees again the strong connection between GDP and $\mathrm{CO} 2$ :s - see Figure 10. It seems that the $\mathrm{CO}$ :s was halted in their expansion for some time, but now they increase again. 


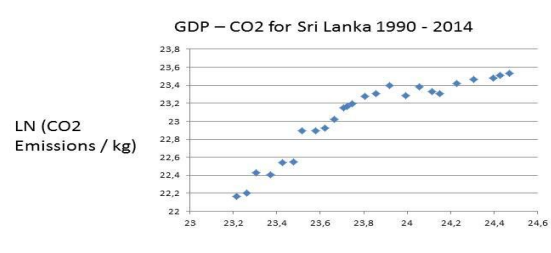

LN (GDP / Constant Value 2005 USD)

Figure 10. Sri Lanka $\left(y=1,03 x ; R^{2}=0,84\right)$

In this island state, the dominant energy source is traditional renewables, which leads to deforestation and $\mathrm{CO} 2$ emissions on a large scale (Figure 11). It has been argued that the forest will grow up again, eating the carbon emissions. But it is mainly wishful thinking, as climate change and draughts make forest rehabilitation difficult.

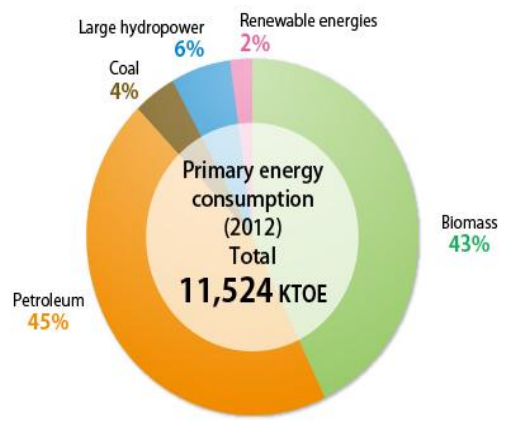

Figure 11. Sri Lanka's Energy Consumption

Source: Primary energy consumption in Sri Lanka (2012).

http://www.info.energy.gov.lk/

To sum up: For the poor nations in Asia with huge population and large emissions holds that they cannot by themselves accomplish the objectives of COP21: Goal I: reverse current $\mathrm{CO} 2$ trend, Goal II: reduce by 40 per cent the CO2:s by 2030 and Goal III: full decarbonisation by 2075 . As a matter of fact, they will need massive financial assistance from the Super Fund, which has still not been founded.

Yet, this requires that the COP21 or CO22 sets up a management structure to assist these countries involving project evaluation, policy execution and implementation, control of financial flows and outcome assessment — a gigantic task with many pitfalls involved.

\subsection{Defection Games}

The giant oil producing countries play a major role for global warming, as they themselves emit much emissions and deliver the energy to others for still more emissions. They face an enormous challenge, 
viz transform its energy mix towards renewables at the same as they reduce their exports. Will they really do this? Only if supported by the Super Fund, as promised in Paris 2015.

Iran

Countries may rely upon petroleum and gas mainly—see Iran (Figure 12). CO2 emissions have generally followed economic development in this giant country, although there seems to be a planning out recently, perhaps due to the international sanctions against its economy.

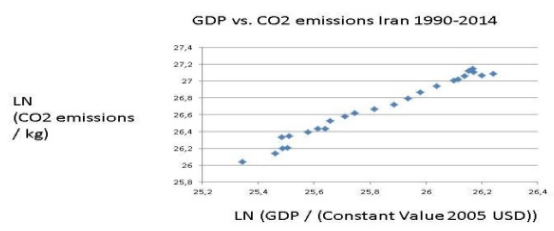

Figure 12. Iran: GDP-CO2 Link $\left(y=1,2229 x-4,91 ; R^{2}=0,98\right)$

Iran is together with Russia and Qatar the largest owner of natural gas deposits. But despite using coal in very small amounts, its $\mathrm{CO} 2$ emissions are high. Natural gas pollute less than oil and coal, but if released unburned it is very dangerous as a greenhouse gas. Iran relies upon its enormous resources of gas and oil (Figure 13).

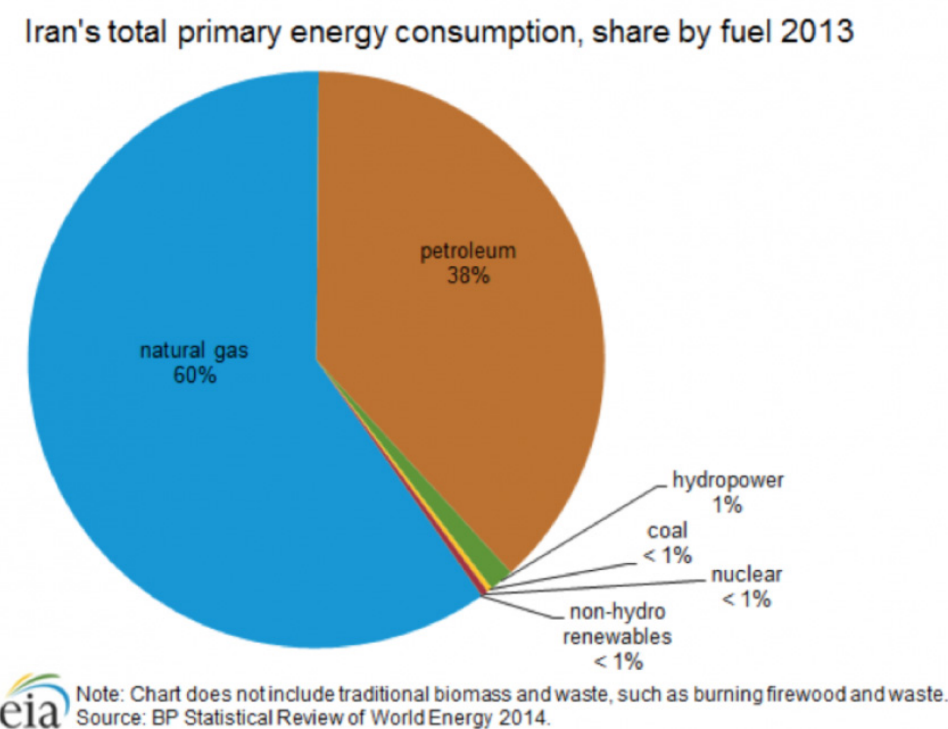

Niate: Chart does not include traditional biomass and
Cource: BP Statistical Review of World Energy 2014.

Figure 13. Iran: Energy Mix

Iran needs foreign exchange to pay for all its imports of goods and services. Using nuclear power at Published by SCHOLINK INC. 
home and exporting more oil and gas would no doubt be profitable for the country. And it would also help Iran with the COP21 goals achievement. One would expect to find huge $\mathrm{CO} 2$ emissions in this large emerging economy with lots of oil production. Countries like the Gulf States have massive CO2:s because they drill and refine oil and natural gas.

For giant oil producer Mexico holds the following situation (Figure 14).

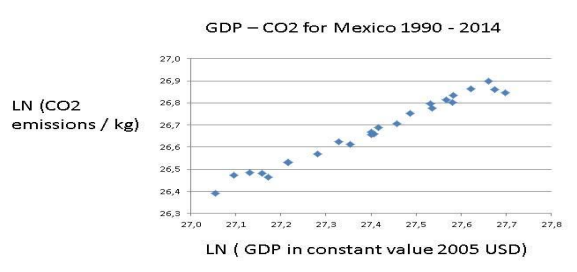

Figure 14. GDP-CO2 in Mexico $\left(y=0,77 x ; R^{2}=0,98\right)$

The close link between economic development and $\mathrm{CO} 2$ is discernable in the data, but the emissions growth seems to stagnate in the last years. This is of course a promising sign, whether it is the start of a COP21 inspired $40 \%$ reduction in CO2:s remains to be seen. I doubt so, but let us enquire into the energy mix of this huge country that is of enormous economic importance to both North and South America (Figure 15).

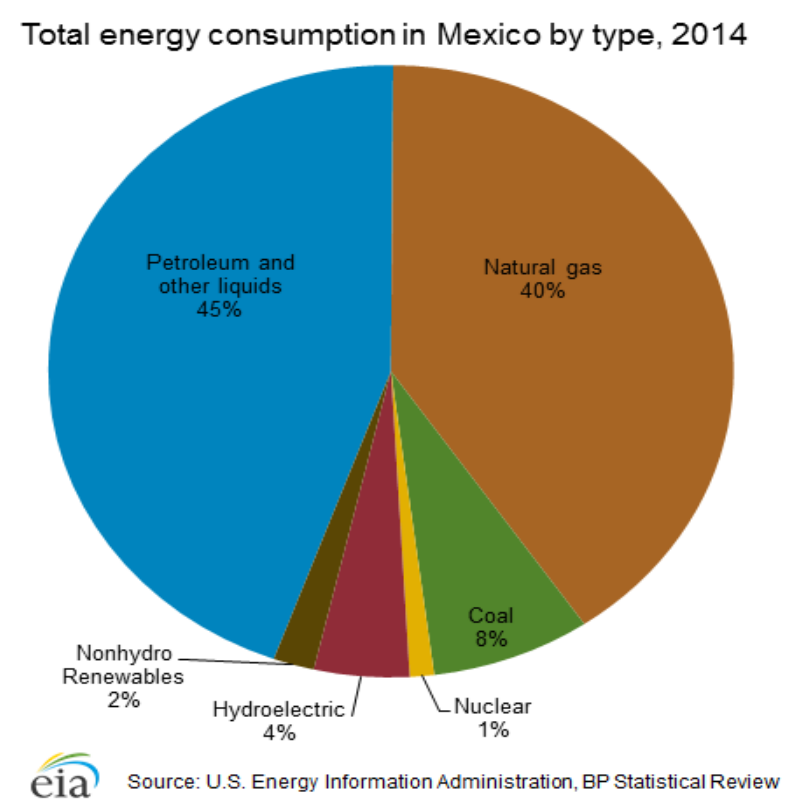

Figure 15. Energy Mix for Mexico 
Few countries are so dependent upon fossil fuels as Mexico. One find the same patter with the oil exporting Gulf States. The Mexican government must start now to reduce this dependency, by for instance eliminating coal and bringing down petroleum, instead betting upon solar, wind and nuclear power. Mexico will face severe difficulties with the $40 \%$ reduction target in COP21. It has a fast growing population with many in poverty and an expanding industry sucking electricity. Can economic growth and decarbonisation go together here?

Also countries with no hydro power display increasing trends for emissions. Consider an oil and gas rich country in Asia (Figure 16).

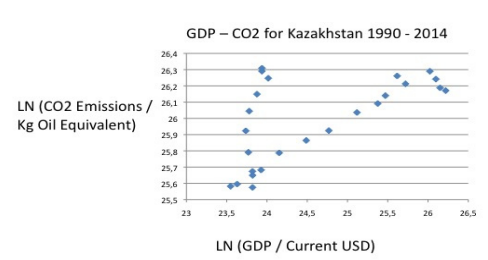

Figure 16. Kazahkstan $\left(y=0,17 ; R^{2}=0,38\right)$

Kazahkstan employs its vast fossil fuel resources for energy consumpton besides exporting a lost. Thee country has big lans for the future, building the new Silk Road from China to Germany, which requires immense new energy. Kazahkstan will of course rely upon its enormous reserves of fossil fuels (Figure 17). 


\section{Kazakhstan's energy consumption by fuel, 2012}

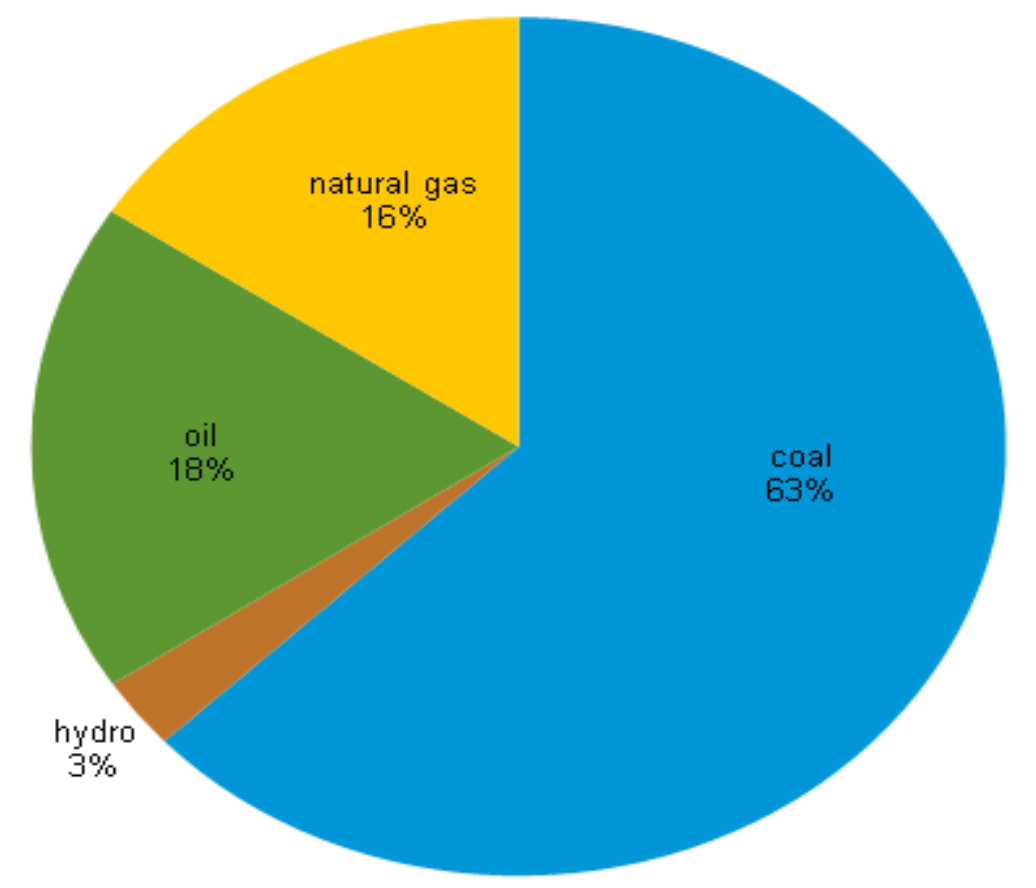

eia Source: U.S. Energy Information Administration

Figure 17. Energy Mix for Kazahkstan

Summing Up: The oil producing countries pose a special challenge to the COP21 project. They rely exclusively upon their fossil fuel resources and need all the export revenues from exporting some of them. If necessary for lack of funds or technology, they will defect upon COP21 goals.

\subsection{Bargaining Strategy: Risk of Sub-Optimization}

A medium income country with a not too large population can innovate, thus promoting decarbonisation by itself. But it may accomplish a more radical change with support from the Super fund, which entails extensive bargaining between the country and international governance bodies. Is a Pareto optimal outcome achievable, making Goal I and Goal II realities as outcomes?

Thailand

Figure 18 begins with Thailand that has become a rapidly developing country with increasing affluence and is besides furnishing large scale tourisma major car producer inter alia. 


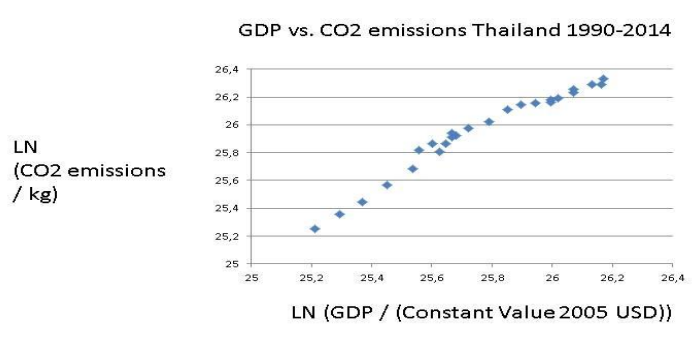

Figure 18. Thailand $\left(y=1,07 x ; R^{2}=0,96\right)$

The $\mathrm{CO} 2$ emissions in Thailand are quite high, reflecting the economic advances in South East Asia. The trend is up and up. Can it be reversed without serious economic impact? Figure 19 shows the energy mix of this dynamic country, economically.

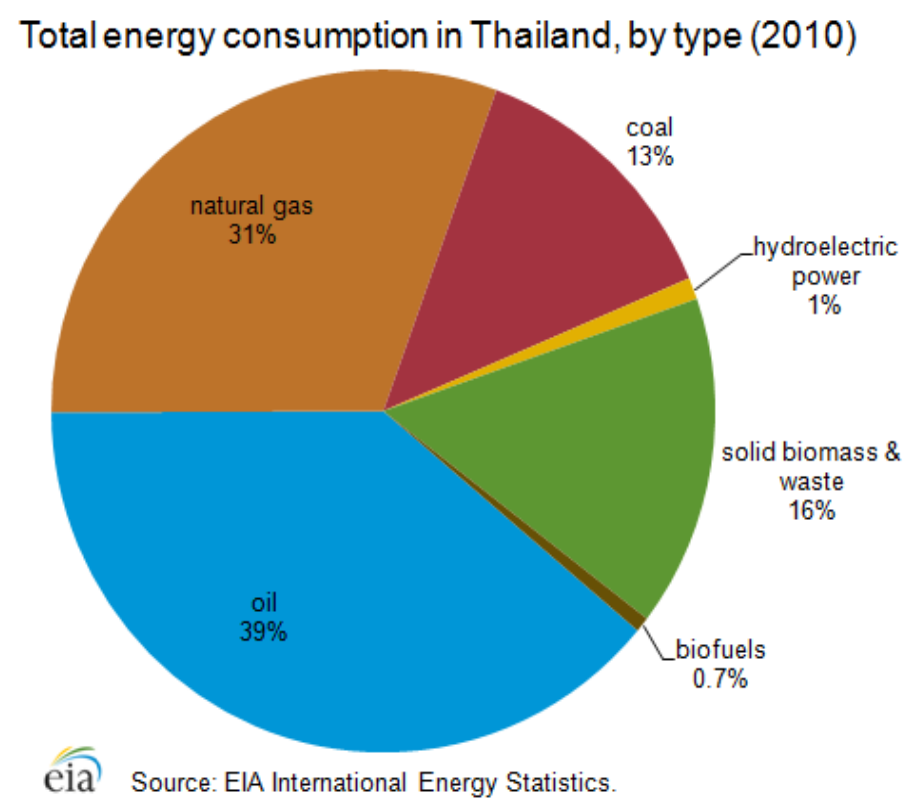

Figure 19. Thailand's Energy Mix

The reliance upon fossil fuels is high, or over $80 \%$ of energy consumption coming from the burning of coal, oil and natural gas. Hydro power is marginal, but bio-energy plays a major role, but it is really not carbon neutral. Thailand needs to come up with far-reaching reforms of its energy sector in order to comply with COP21 objectives.

Malaysia

The overall situation — fossil fuels dependency — is the same for Malaysia as for Thailand. And the Published by SCHOLINK INC. 
$\mathrm{CO}$ :s are high, following the GDP trend (Figure 20).

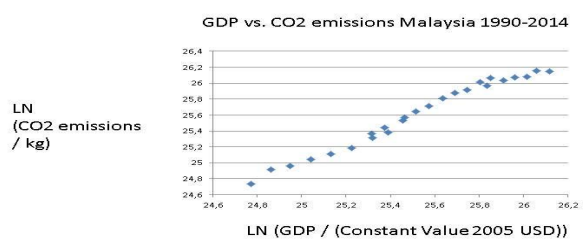

Figure 20. Malaysia $\left(y=1,13 x ; R^{2}=0,98\right)$

Yet, Malaysia employs energy of a very mixed bag (Figure 21), but still its emissions augment in line with economic development. There may be a planning out of the growth trend in emissions recently, but Malaysia use very little of carbon neutral energy sources. There is hydro power, but the country must move to solar and wind power rapidly.

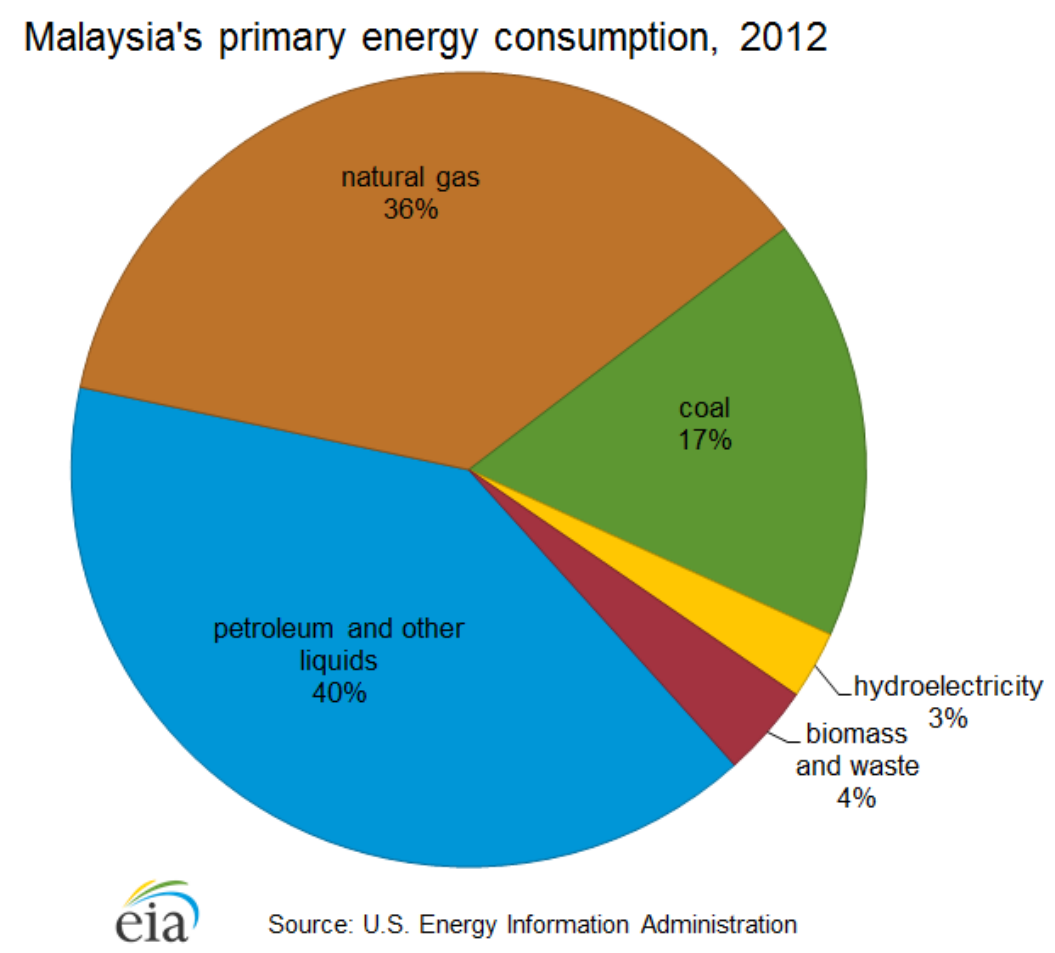

Figure 21. Energy in Malaysia

Renewables are not a major element in the energy consumption mix of Malaysia, as fossil fuels dominate, but not coal luckily.

Vietnam and the Philippines

To further substantiate the argument about the $\mathrm{CO} 2$-energy conundrum that countries all over the world 
face, we may look at two populous nations in Asia with quickly expanding economies: Vietnam and the Philippines. They have both upward sloping trends for emissions, energy consumption and GDP, as the Kaya model entails.

Vietnam is now the perhaps most dynamic economy in Asia, after years of socialism and a planned economy. Such fast economic growth requires one thing especially, namely energy (Figure 22).

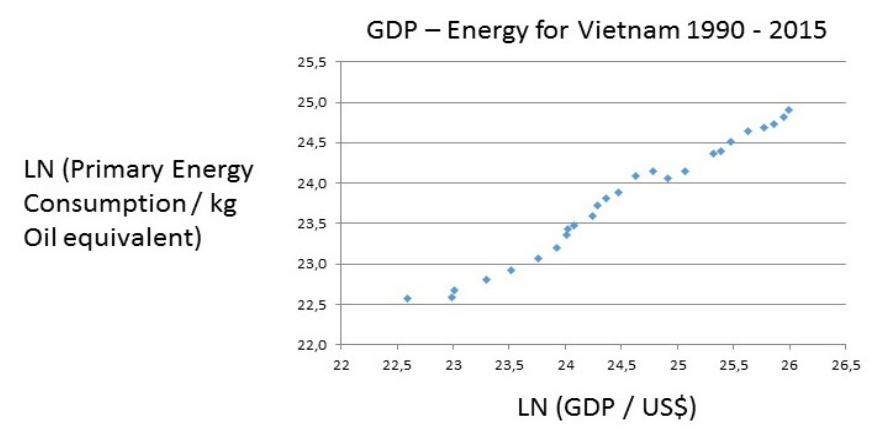

Figure 22. Vietnam: GDP and Energy $\left(y=0,74 x ; R^{2}=0,98\right)$

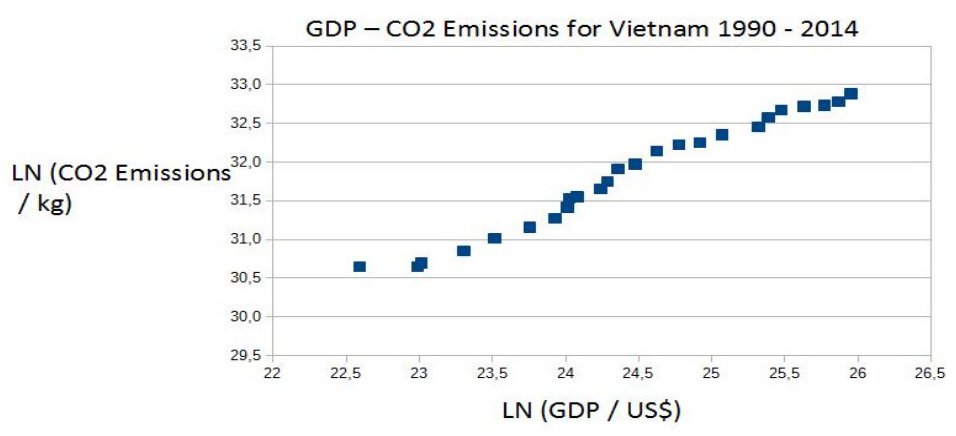

Figure 23. GDP and Emissions for Vietnam $\left(f(x)=.75 x+13.37 ; 0.98 ; R^{2}=0.98\right)$

The benefits of such a strong economic development is of course raising affluence and diminishing poverty. But the costs involve much more emissions (Figure 23).

How Vietnam is to change in order to promote the COP21 goals, Goal I and Goal II within a short period of some 10 years, given the ambition to maintain raid economic growth, is very difficult to understand. Can really renewables do the trick? It is a highly relevant policy question, despite the massive employment of hydro power in this country.

Giant nation the Philippines is very interesting, as they claim that they can handle the implementation of the COP21 goals. This may simply be rhetoric, which is just another form of reneging upon promises. Consider first the upward sloping trend in Figure 24. 


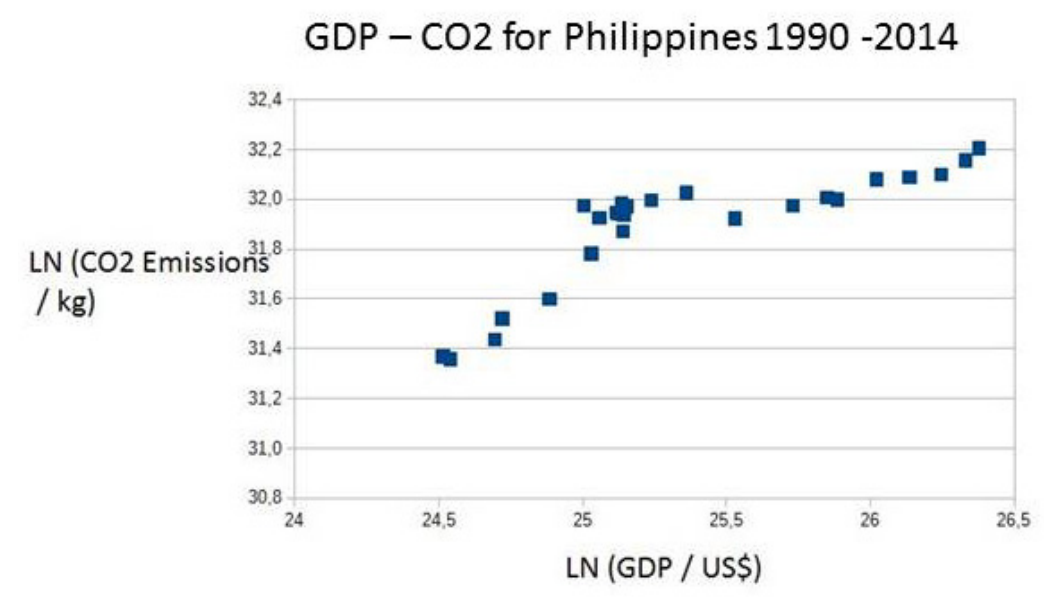

Figure 24. The Philippines $(f(x)=0.35 x+23.01 ; R 2=0.68)$

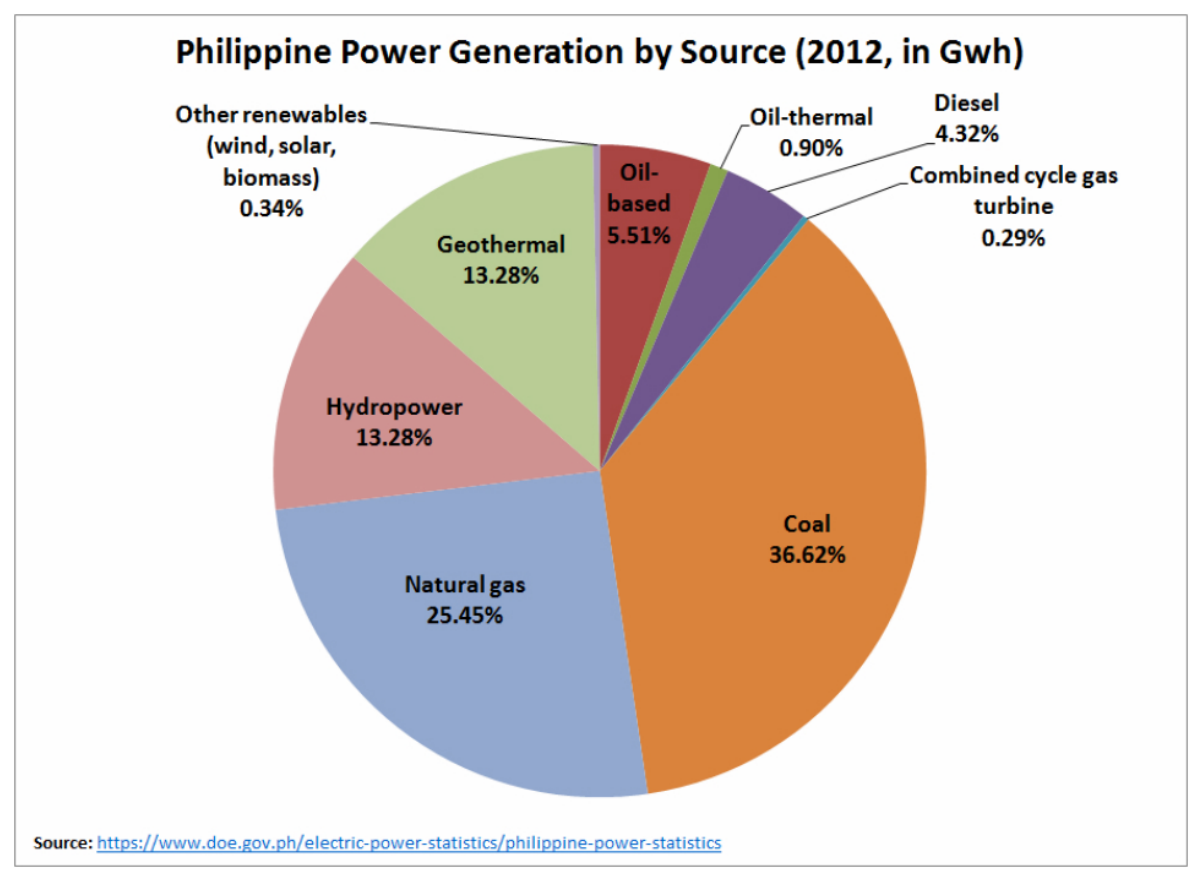

Figure 25. Energy Mix in the Philippines

The energy profile of the Philippines is actually more positive than several of the countries above, including a huge part of geo-thermal energy. Yet, fossil fuels dominate to a high 70 per cent, as in other populous and rapidly developing nations. The Philippines definitely needs help from the Super Fund.

Summary: The caching-up countries all have increasing slopes for the GDP-CO2 link, which entails profound difficulties to come for the accomplishment of Goal I in the CO21 project. In relation to the achievement of Goal II, one can say only note that tremendous investments have to be made by these countries in renewable energy and atomic plants, which they will find difficult to do.

\subsection{Only Second Best Solutions}

A few nations do not depend upon any foreign assistance, because they are highly developed Published by SCHOLINK INC. 
technologically and can draw upon own substantial financial resources. One may find that the emissions of GHG:s follows economic development closely in many countries. The basic explanation is population growth and GDP growth-more people and higher life style demands. Take the case of China, whose emissions including CO2:s are the large stin the world, totally speaking (Figure26). China was a Third World country upuntil yesterday.

China

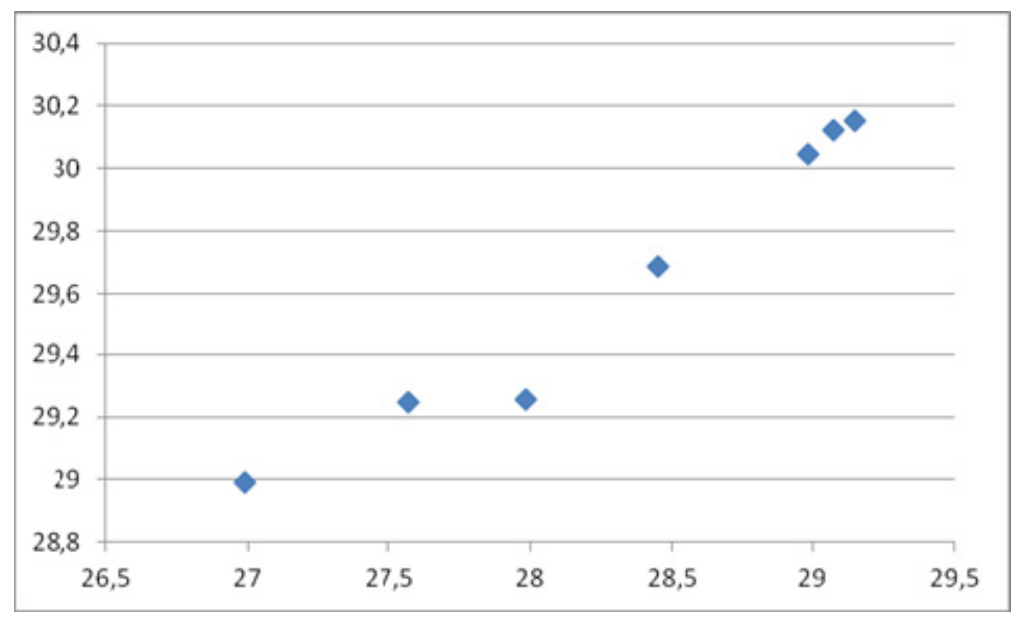

Figure 26.China $\left(y=0,7025 x ; R^{2}=0,97\right)$

Note. $\mathrm{GHG}=\mathrm{y}$-axis, $\mathrm{GDP}=\mathrm{x}$-axis.

The sharp increase in GHG:s in China reflects not only the immensely rapid industrialization and urbanization of the last 30 years, but also its problematic energy mix (Figure 27).

\section{Chinu Primary Entrog Mix (2013)}

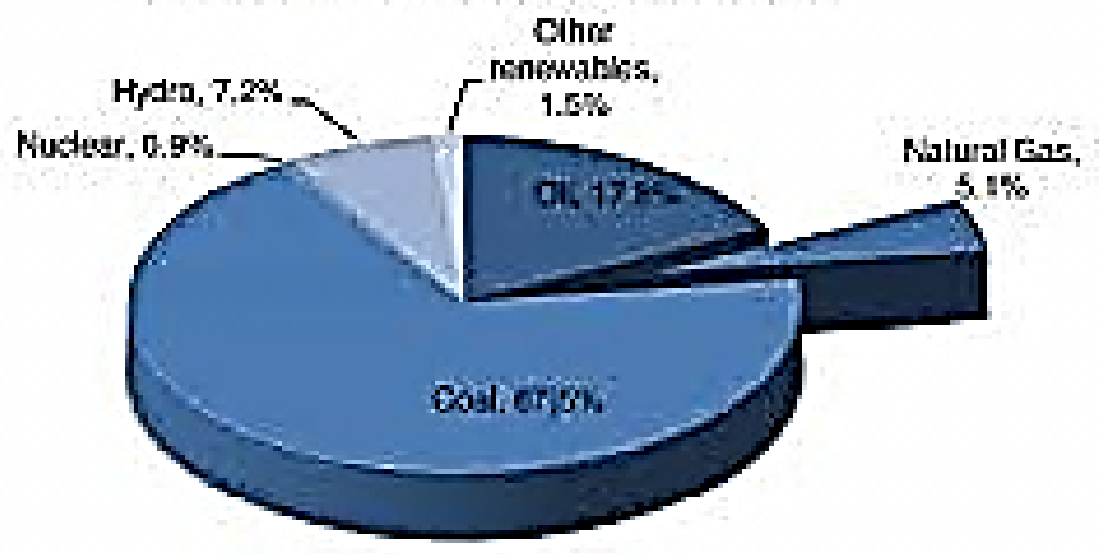

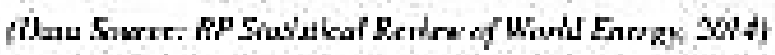

Figure 27. Energy Consumption in China 
Almost 70 per cent of the energy consumption comes from the burning of coal with an additional 20 per cent from other fossil fuels. The role of nuclear, hydro and other renewable energy sources is small indeed, despite new investments. This makes China very vulnerable to demands for cutting GHG emissions: other energy sources or massive installation of highly improved filters?

It should be pointed out that several small countries have much higher emissions per capita than China. This raises the enormously difficult problematic of fair cuts of emissions. Should the largest polluters per capita cut most or the biggest aggregate polluters? At COP21 this issue was resolved by the creation of a Super Fund to assist energy transition and environment protection in developing counties, as proposed by economist Stern (2007). But China can hardly ask for this form of foreign assistance. It is true that China energy consumption is changing with much more of renewables ad atomic plants. But so is also demand increasing with new and bigger cars all the time plus increased air traffic on huge new airports. Can China really cut $\mathrm{CO} 2$ :s with 40 per cent while supply almost 50 per cent more energy power, according to plan?

\section{South Korea}

Industrial giant South Korea is very interesting frm the perspective of the COP21 Agreement, because the basic trend violates both Goal I and Goal II. Anentirely different trend than that of other mature economies is to be found in South Korea (Figure 28), which has "caughtup" in a stunning speed but with enormous GHG emissions.

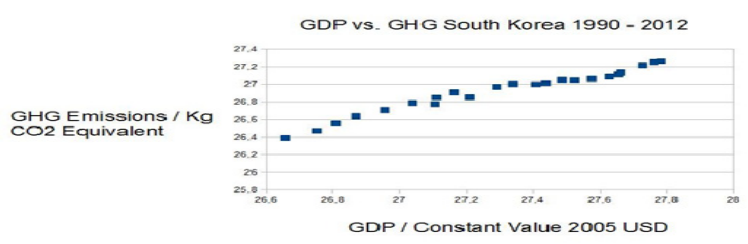

Figure 28. South Korea $\left(y=0,646 x+9,19\left[R^{2}=0,9604\right]\right)$

Lacking much hydro power, South Korea has turned to fossil fuels for energy purposes, almost up to 90 per cent (Figure 29). Now, it builds nuclear plants, but South Korea needs to move aggressively into solar power to reverse trends. 


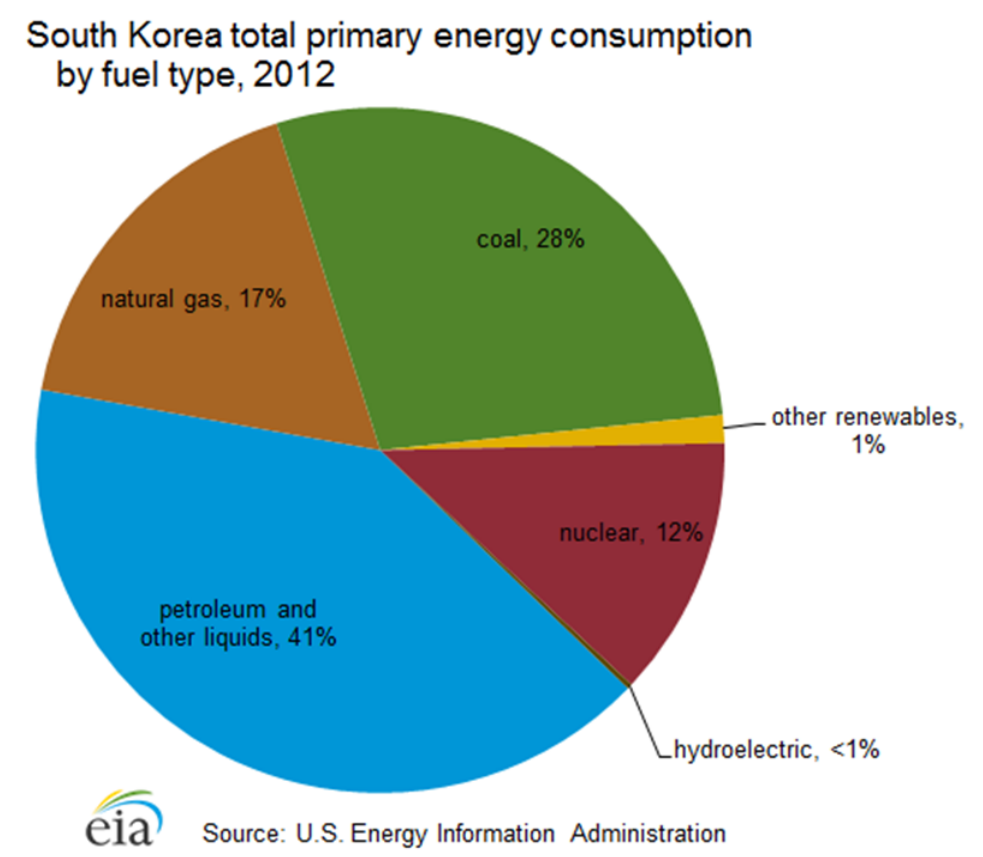

Figure 29. Energy in South Korea

It differs from China only in the reliance upon nuclear power, where the country is a world leader in plant constructions. Reducing its GHG emissions, South Korea will have to rely much more upon renewable energy sources, as well as reducing coal and oil for imported gas or LNGs.

Australia

When one goes beyond the EU, one finds only two cases of declining GDP-COP curve: Australia and Japan. Japan has for a long time substituted coal for atomic power, although recently with a crucial set back. But Australia has always been the country of fossil fuels, exporting coal and iron in huge amounts. However, it has reached its $\mathrm{CO} 2$ peak very recently (Figure 30). 
LN (CO2 Emissions / kg of oil equivalent)

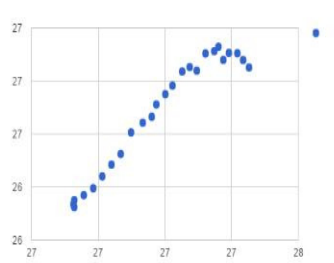

LN (GDP / Constant Value 2005 \$)

Figure 30. Australia's Link GDP-CO2

Exports Australia has been extremely dependent upon fossil fuels, domestically and in. Cutting back its coal dependency will allow the country to halt its $\mathrm{CO} 2$ emissions, while moving to renewables. The fossil fuel dependency of Australia is simply stunning (Figure 31).

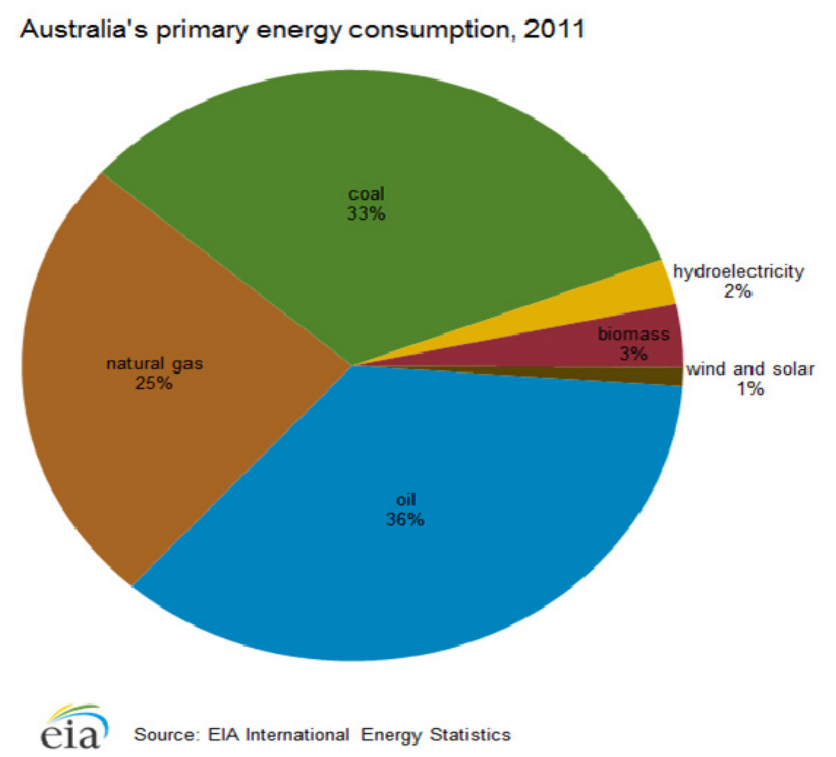

Figure 31. Energy Mix in Australia

Australia has often been accused of fuelling climate change. These accusations appear to be vindicated in the Figure above that shows an extreme reliance upon fossil fuels. Add then all the export of raw materials! One prime minister of Australia has declared that the country will reduce CO2:s only if economic growth is not hurt. It remains to be seen how Australia tackles Goal I and Goal II. Former premier Abbott expressed an Australian preference: first growth, second decarbonisation. 
Summing up: Neither China nor South Korea are on line for fulfilling the COP21 Goal I, as they are not reducing their emissions, like other advanced or mature economies as Japan, the EU and some EU nations. Goal II seems far away in terms of achievement for these two industrial giant, still very dependent upon fossil fuels. They innovate with renewables, but hope to consume even more energy in the coming decade. Australia's Tony Abbott has declared that economic growth trumps the CP21 goals.

\section{The Super Fund}

The basic argument here is that the achievement of decarbonisation according to the COP21 goals (I-III) is going to stumble upon the implications of the Kaya model, namely that $\mathrm{CO} 2$ emissions are fundamentally driven by economic forces, like the GD per capita and the size of the population besides energy and carbon intensity. To make it feasible for large poor countries to reduce $\mathrm{CO} 2$ emissions but yet maintain a decent level of economic development, the Super Fund must be made operative. Yet, it does not even "exist" in a more articulate form on paper. Countries in South Asia could not bear the costs in large scale energy transformation alone, let alone also fund policies against poverty. Several countries may accomplish superior outcomes, if funding I shared with the Super Fund.

It seems that the already existing Green Climate Fund may be transformed into the Super Fund with a budget of 100 billion a year, but it would have to be completely restructured. The management tasks involved are enormous, not to talk about the financing. The Third World will keep reminding the First World about this promise, which constitutes a sine qua non.

Could the financing come from a Tobin tax or perhaps a global carbon tax? If so, global stock markets will become involved, this has not happened yet. Many First World countries are direly indebted, like the EU and the US. If financing is very uncertain, then the implementation of projects faces enormous hurdles in the form of cost efficiency, risk of corruption and embezzlement as well as conflicts between national, regional or local governmentsand international bodies. The implementation of the COP21 goals requires a firm state with capacity to deliver on policies, but many Third World countries have weak or fragmented states.

Global markets are characterized by myopia, meaning that they will not react to the giant market failure than climate change tis conducive to, until it is too late. For now, it is business as usual: more air transportation, bigger cars, rapid urbanisation and a swelling demand for electricity. The use of coal is going down, which is very positive, but the number of cars is increasing in the huge countries. And giant cement constructions still come up in for instance Dubai.

\section{Conclusion}

It seems that it is business as usual now months after the CO21 Agreement in Paris 2015. Nations plan for continued economic development with large projects requiring lots of new energy. It is hoped that renewables and electricity will solve the global warming problematic, replacing the fssil fuels and offering new energy to consume. Where is all this electricity for industry, agriculture, housing and 
transportation to come from? And how is the gigantic energy transformation to be managed with proper incentives in key countries?

Social science modelling of policy implementation (Wildavsky's hiatus) and energy-GD-emission links (Kaya's model) do not at all support any optimism about reversing the climate change process. The talk about the coming of a sustainable economy (Sachs, 2015) is utopian figment of the imagination. The trend upwards in Figure 32 must be reserved strongly pretty soon.

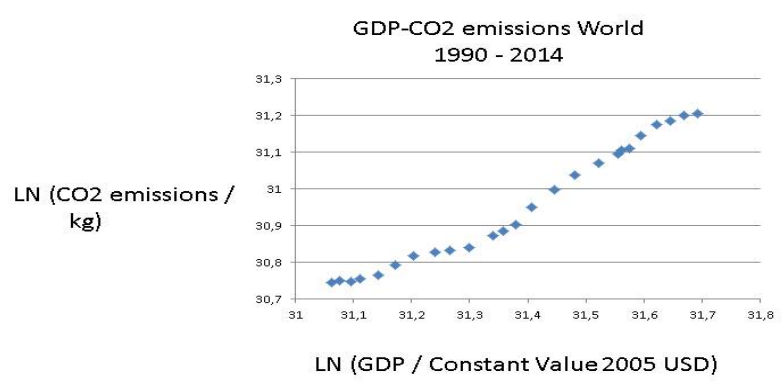

Figure 32. Global Link between GDP and CO2:s $\left(y=0,80 x+5,96 ; R^{2}=0,97\right)$

\section{Refrences}

\section{GDP Sources}

World Bank national accounts, http://www.data-data.worldbank.org

OECD National Accounts data files.

\section{GHG and Energy Sources}

World Resources Institute CAIT Climate Data Explorer, http://www.cait.wri.org

EU Joint Research Centre Emission Database for Global Atmospheric.

Research-http://www.edgar.jrc.ec.europa.eu/overview.php

UN Framework Convention Change

http://www.unfccc.int/ghg_data/ghg_data_unfccc/time_series_annex_i/items/3814.php

International Energy Agency. Paris.

Energy Information Administration. Washington, DC.

BP Energy Outlook 2016.

EU Emissions Database for Global Research EDGAR, http://www.edgar.jrc.ec.europa.eu/

World Bank Data Indicators, http://www.data.worldbank.org

British Petroleum Statistical Review of World Energy 2016. 


\section{Literature}

Pressman, J., \& Wildavsky, A. (1973, 1984). Implementation. Berkeley: University of California.

Sachs, J. (2015). The Age of Sustainable Development. New York: Columbia University Press. http://dx.doi.org/10.7312/sach17314

Kaya, Y., \& Yokoburi, K. (1997). Environment, energy, and economy: Strategies for sustainability. Tokyo: United Nations University Press.

Stern, N. (2007). The Economics of Climate Change. Oxford: Oxford University Press. http://dx.doi.org/10.1017/CBO9780511817434

Wildavsky, A. (1979, 1987). Speaking Truth to Power. Piscataway: Transaction. 